\title{
Trade Openness and Urban Concentration: New Evidence
}

\author{
Volker Nitsch \\ Free University Berlin
}

\begin{abstract}
In this paper, I reexamine the empirical relations hip between trade openness and urban concentration. Using a panel data set of more than 110 countries for the period from 1970 through 2000, I find that previous results of a negative association between trade openness and the size of a country's largest city are not robust. More importantly, the openness-concentration link disappears completely, once reverse causality and the endogeneity of trade are accounted for. There is no evidence that trade liberalization significantly reduces urban concentration. Similarly, openness is insignificant if trade is instrumented by geographic characteristics.
\end{abstract}

- JEL classification: F15, R12

- Keywords: Liberalization, Primacy, Trade, Policy, Location

\section{Introduction}

This short paper deals with the question "Is there a relationship between a country's external trade and its internal geography?" or, more precisely, "Does openness matter for urban concentration?" This issue is of interest for at least two reasons.

First, policy-makers and academics are increasingly concerned about excessive concentration; especially in developing countries a disproportionately large share of a country's urban population appears to be concentrated in one or two major

\footnotetext{
*Corresponding address: Volker Nitsch, Freie Universitat Berlin, FB Wirtschaftswissenschaft, Boltzmannstrasse 20, 14195 Berlin, Germany, Tel.: 030-838-56280, Fax: 030-838-54142, E-mail: volker.nitsch@ wiwiss.fu-berlin.de (2006-Center for International Economics, Sejong Institution, All Rights Reserved.
} 
metropolitan areas (mega-cities) that strongly dominate the national urban structure. The World Bank (2003, p. 139), for instance, notes in its World Development Report 2003: "[T] he spatial distribution of economic activity in general, and of urban centers in particular, is important to sustainable development. ... Excessive primacy can have real economic efficiency costs to countries." Vernon Henderson (2003) estimates that a deviation from the best primacy level by about 0.1 is associated with a loss in productivity growth by about 0.6 percent a year. If there is an association between openness to international trade and urban concentration, however, changes in trade policy may be a useful strategy to decentralization.

Second, while for a long time the prevailing view was that the empirical relationship between openness and urban concentration is ambiguous and perhaps positive (with large merchant cities benefiting from a liberal trade regime), there now appears to be a new consensus that the effect is exactly the opposite: negative and significant. Paul Krugman (1996, p. 13), for instance, claims that it is one of four stylized facts about urban size distributions that "[m]ore open economies, as measured by the share of exports in gross domestic product, tend to have smaller biggest cities". There are basically three pieces of evidence that support this claim. Several studies by Gordon Hanson document for the case of Mexico that trade liberalization is accompanied by decentralization; the removal of trade barriers initiated in the mid-1980s appears to have contributed to a relocation of the Mexican industry away from Mexico City toward the northern border of the country (see, for instance, Hanson [1998] and Krugman and Hanson [1993]). Krugman and Raul Livas Elizondo (1996) formalize this story; they develop a model in which access to external markets weakens the agglomeration forces inside the economy, making it more likely that the country's internal structure is spatially dispersed. Finally, Alberto Ades and Edward Glaeser (1995) find in a cross section sample of 85 countries that the share of trade in GDP is negatively related to the size of the largest city, holding other things constant.

In this paper, I reexamine the empirical relationship between trade openness and urban concentration. I do so, first, by exploring the association between a country's trade-to-GDP ratio and the size of its largest city in a large cross country sample that covers more than 110 countries. Using a standard cross-section framework (similar to Ades and Glaeser), I find indeed a significantly negative relationship between openness and urban concentration. However, the effect is not robust. For instance, the estimated trade effect on concentration seems to be highly sensitive to 
the regression specification. More importantly, a significant coefficient on trade openness does not necessarily reflect a causal relationship between trade and city size. As Ades and Glaeser put it (p. 224): "Trade and cities are connected, but it may be that urban concentration is causing low levels of trade, not that low levels of trade induce concentration."

In a next step, therefore, I deal with the possible problem of reverse causality. To check whether external trade is a determinant of urban concentration, I focus on trade policy (instead of openness) and explore the effects of changes in a country's trade regime on urban structure. With this modification, I find no evidence that urban concentration is related to external openness; trade liberalization appears to have no measurable effect on urban primacy. To control more directly for the likely endogeneity of trade, I then apply an instrumental variables approach. As before, the results suggest that ordinary least-squares regressions of primacy on openness strongly overstate the effects of trade. If geographic characteristics are used as an instrument for trade, the statistical association between openness and urban concentration becomes essentially zero.

The remainder of the paper is organized as follows. In the next section, I shortly review the relevant literature. Section 3 presents the estimation approach and the data. The empirical results are discussed in section 4 . The paper ends with a brief conclusion.

\section{Related Literature}

There is a large (and still growing) literature that seeks to explain differences in the city-size distribution across countries. In these studies, in order to identify potential determinants of urban concentration, typically a (self-defined) measure of urbanization is related to a (long) list of economic variables; a list that also occasionally includes a country's openness to international trade. Recent examples for this line of research include Ronald Moomaw and Ali Shatter (1996), Karsten Junius (1999), Henderson (2002b), and Moomaw and Mohammed Alwosabi (2004); earlier work is surveyed in Glenn Carroll (1982).

Reviewing these studies for evidence on the link between trade openness and urban concentration, the results appear to be generally mixed. For one thing, the estimated coefficients on trade openness vary considerably. Results by Kwok Tong Soo (2003), for example, suggest that there is no significant association between the trade-to-GDP ratio and the shape of the size distribution of cities. More 
importantly, many empirical studies on urban concentration do not even include a measure of external openness; see, for instance, Servet Mutlu (1989) and Gershon Alperovich (1993). ${ }^{1,2}$

The most prominent study, then, that explores the empirical determinants of urban concentration and finds a negative effect of trade openness is a paper by Ades and Glaeser (1995). This paper is extremely comprehensive. In order to determine the factors behind the centralization of a nation's urban population in a major city, they (i) propose a simple theoretical model (to capture the effects of government and politics on urban primacy), (ii) analyze historical case studies, and (iii) explore cross-country evidence. However, since their study is mainly concerned with identifying the impact of political forces on the national urban structure, they provide only a limited number of results on the effect of trade openness. In the following, I focus explicitly on the impact of trade openness on urban concentration.

\section{Methodology and Data}

For simplicity (and comparability), I use Ades and Glaeser's (1995) crosssectional estimation approach as benchmark specification; at a later stage, I will modify and extend this specification. In particular, I estimate an equation of the form:

$$
\ln (\text { City })=\alpha+\Sigma_{i} \beta_{i} x_{i}+\Sigma_{j} \gamma_{j} y_{j}+\delta \ln (\text { Trade })+\varepsilon
$$

where CITY is the population size of a country's largest city; the $x_{i}$ 's are scale variables for city size: the log of the country's total nonurbanized population and the $\log$ of population in other urbanized areas; $j$, is a vector of other controls that have the potential to affect the size of the country's largest city, such as the log of land area, the log of real GDP per capita, and the share of labor force outside of agriculture; and TRADE is the variable of interest: the country's trade-to-GDP ratio.

\footnotetext{
${ }^{1}$ Due to the small number of studies that actually report empirical results on the effect of trade openness on urban concentration, meta-analysis to combine and explain these (disparate) estimates is not a useful approach.

${ }^{2}$ A number of recent studies highlight this ambiguity. Rasha Gustavsson (1999) finds for developing countries that an open trade regime tends to increase urban primacy. Moomaw and Alwosabi (2003) forcefully question this result. For a sample of 30 countries in Asia and the Americas, they find an insignificant or negative association between openness and concentration, depending on specification.
} 
The data are compiled from a number of different sources. City population data are taken from the United Nation's World Urbanization Prospects: The 2001

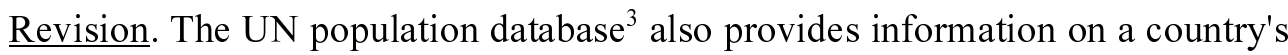
total, urbanized and nonurbanized population. Data on real GDP per capita and the share of trade in GDP are from the Penn World Table mark 6.1. Finally, data on the land area and the share of labor force outside agriculture are obtained from the World Bank's World Development Indicators. Following Ades and Glaeser, I obtain data in five-year intervals and then average the data over fifteen-year periods; all results remain basically unchanged when I use ten-year periods instead of the fifteen-year periods. In total, my sample covers 115 countries for the period from 1970 through $2000 .^{4}$

\section{Empirical Results}

\section{A. Benchmark results}

I begin by exploring the openness-concentration link in a standard cross-country framework. The first two columns in Table 1 present the benchmark results; they tabulate the estimates for the two fifteen-year intervals from 1970 through 1985 and from 1985 through 2000 . As shown, the estimation results are fairly robust over time. Also, the model fits the data remarkably well; more than 80 percent of the variation in the dependent variable is explained with the equation. The most notable observation, however, is that most of the coefficients take on the expected sign and are statistically significant. The size of a country's largest city rises with the country's total population, although only the coefficient on the log of nonurbanized population is consistently (economically and statistically) significant. Also country size matters; the point estimate implies that an increase in country size by 10 percent increases the population in the main city by about 0.9 percent. Finally, more developed economies tend to have larger central cities. This effect is completely captured by the share of labor force outside agriculture while the coefficient on real GDP per capita is not significantly different from zero.

Turning to the main variable of interest, the coefficient on the share of trade in

\footnotetext{
${ }^{3}$ Available at http://esa.un.org/unpp.

${ }^{4}$ It should be noted that all results concerning the relationship between openness and concentration crucially depend on the exclusion of Hong Kong and Singapore. If the two highly open city states are included, the coefficient on the share of trade in GDP becomes clearly positive.
} 
GDP is negative, statistically highly significant and almost of the same magnitude as in Ades and Glaeser (1995). The elasticity of about -0.7 suggests that an increase in the openness ratio by 10 percent reduces the size of the largest city by about 7 percent.

If lagged (instead of contemporary) values of trade openness are used as explanatory variable (as a first crude check to examine causality), the results remain basically unchanged. The last column in Table 1 presents estimates for the period from 1985 to 2000 , entering average trade openness in the previous fifteenyear interval as regressor. With this specification, the coefficient on the openness variable slightly increases in size but, at the same time, loses somewhat in statistical significance.

To summarize, the evidence from averaged cross-country data basically supports the hypothesis of a negative relationship between trade openness and the size of the largest city. It seems that trade liberalization reduces the average size of the central

Table 1. Benchmark Results

\begin{tabular}{lccc}
\hline Time period & $1970-85$ & $1985-2000$ & $1985-2000$ \\
\hline Capital city dummy & $0.509^{* *}$ & $0.480^{* *}$ & $0.468^{* *}$ \\
Log of nonurbanized population & $(0.140)$ & $(0.148)$ & $(0.147)$ \\
Log of urbanized population outside the main city & $0.582^{* *}$ & $0.421^{* *}$ & $0.406^{* *}$ \\
& $(0.059)$ & $(0.066)$ & $(0.069)$ \\
Log of land area & $(0.047)$ & $(0.063)$ & $0.135^{*}$ \\
& $0.085^{*}$ & $0.090 \#$ & $0.100^{*}$ \\
Log of real GDP per capita & $(0.040)$ & $(0.047)$ & $(0.047)$ \\
Share of the labor force outside of agriculture & $0.295 \#$ & 0.102 & 0.146 \\
Share of trade in GDP & $(0.166)$ & $(0.109)$ & $(0.106)$ \\
& $2.151^{* *}$ & $1.964^{* *}$ & $1.756^{* *}$ \\
Share of trade in GDP, lagged & $(0.603)$ & $(0.450)$ & $(0.433)$ \\
& $-0.682^{* *}$ & $-0.722^{* *}$ & \\
\hline Number of observations & $(0.251)$ & $(0.223)$ & $-0.743^{*}$ \\
\hline Adjusted R ${ }^{2}$ & & & $(0.296)$ \\
\hline
\end{tabular}

Notes: OLS estimation. Dependent variable is the log of population in the main city. The regressions are based on averaged data for the given period, available in five-year-intervals. White heteroskedastic-consistent standard errors are in parentheses. $* *, *$ and \# denote significant at the $1 \%, 5 \%$ and $10 \%$ level, respectively. Constant not reported. 
city. In the following, I will examine the robustness of this result. ${ }^{5}$

\section{B. Does a city's geographic location matter?}

A first extension deals with an issue that has recently attracted considerable interest: the potential importance of the main city's geographic location within a country. The idea is that an increase in a country's openness to international trade particularly benefits locations close to the border. While these areas have a locational disadvantage in a closed economy, being geographically remote and lacking some rural hinterland, they become increasingly attractive as trade barriers come down, providing good access to international markets. As a result, trade liberalization may increase (rather than decrease) urban primacy if a country's largest city is located on the periphery and thus can be expected to grow through increased trade and commerce. Based on these considerations, Henderson (1996, p. 33) concludes that "the impact of trade on national space is situation-specific, depending on the precise geography of the country."

To control for city location, I experiment with two variables. A first dummy variable takes the value of one if the primate city is a port; this variable is quite common in the literature (e.g., Henderson [2000]; see also Jordan Rappaport and Jeffrey Sachs [2003]). Port cities, located on the coastal periphery of a country, typically benefit from international trade and thus are often disproportionately large. A second dummy variable focuses more directly on a country's internal geography. It is defined to take the value of one if the main city is located close to the geographic center of the country. Specifically, the variable is constructed by calculating the distance of the city from the approximate geographic center of the country, as given by the latitude and longitude figures in the CIA's World Factbook ${ }^{6}$, relative to country size. If the distance is less than one-half of the square root of the land area of the country, a city is assumed to have a central location. While this definition is arbitrary, it turns out to work well in practice. There are only very few cities with a relative distance close to this (critical) parameter so that the particular choice of the parameter has little effect on the composition of the groups. Also, experimentation with the raw relative distance measure (instead of a binary dummy variable) yields basically similar (non-)results. An appendix lists the classification of cities. ${ }^{7}$

\footnotetext{
${ }^{5}$ I have also tested for a nonmonotonic relationship between openness and concentration. Adding quadratic terms, however, does not affect the main results.

${ }^{6}$ Available at http://www.cia.gov/cia/publications/factbook.
} 
The results are reported in Table 2. As shown in the first column, there is indeed evidence that primate cities are disproportionately large if they are located on the coast rather than on an interior site. The estimated coefficient on the port city dummy is positive and economically reasonable, though only of marginal statistical significance. Further, similar to Henderson (2000), the raw effect of port is halved

Table 2. Does Geographic Location Matter?

\begin{tabular}{|c|c|c|c|c|c|}
\hline \multirow{2}{*}{$\frac{\text { Time period }}{\text { Capital city dummy }}$} & \multicolumn{5}{|c|}{$1970-85$} \\
\hline & $0.559 * *$ & $0.558 * *$ & $0.499 * *$ & $0.494 * *$ & $0.507 * *$ \\
\hline & $(0.144)$ & $(0.144)$ & $(0.152)$ & $(0.153)$ & $(0.151)$ \\
\hline \multirow[t]{2}{*}{ Log of nonurbanized population } & $0.590 * *$ & $0.587 * *$ & $0.580 * *$ & $0.577 * *$ & $0.577 * *$ \\
\hline & $(0.057)$ & $(0.060)$ & $(0.060)$ & $(0.061)$ & $(0.060)$ \\
\hline \multirow{2}{*}{$\begin{array}{l}\text { Log of urbanized population outside } \\
\text { the main city }\end{array}$} & 0.026 & 0.029 & 0.036 & 0.038 & 0.032 \\
\hline & $(0.046)$ & $(0.048)$ & $(0.048)$ & $(0.050)$ & $(0.050)$ \\
\hline \multirow[t]{2}{*}{ Log of land area } & $0.096^{*}$ & $0.100 *$ & $0.085^{*}$ & $0.087^{*}$ & $0.107 * *$ \\
\hline & $(0.040)$ & $(0.041)$ & $(0.041)$ & $(0.040)$ & $(0.041)$ \\
\hline \multirow[t]{2}{*}{ Log of real GDP per capita } & $0.294 \#$ & $0.288 \#$ & $0.294 \#$ & $0.291 \#$ & $0.283 \#$ \\
\hline & $(0.157)$ & $(0.150)$ & $(0.166)$ & $(0.173)$ & $(0.153)$ \\
\hline \multirow{2}{*}{$\begin{array}{l}\text { Share of the labor force outside of } \\
\text { agriculture }\end{array}$} & $2.177 * *$ & $2.192 * *$ & $2.146^{* *}$ & $2.151 * *$ & $2.176^{* *}$ \\
\hline & $(0.570)$ & $(0.557)$ & $(0.610)$ & $(0.622)$ & $(0.564)$ \\
\hline \multirow[t]{2}{*}{ Share of trade in GDP } & $-0.696 * *$ & $-0.795 \#$ & $-0.680 * *$ & -0.645 & \#-0.709 \\
\hline & $(0.242)$ & $(0.424)$ & $(0.251)$ & $(0.327)$ & $(0.589)$ \\
\hline \multirow[t]{2}{*}{ Port city dummy } & $0.199 \#$ & 0.103 & & & 0.179 \\
\hline & $(0.106)$ & $(0.246)$ & & & $(0.280)$ \\
\hline \multirow[t]{2}{*}{ Port city $\times$ Share of trade in GDP } & & 0.165 & & & 0.121 \\
\hline & & $(0.434)$ & & & $(0.515)$ \\
\hline \multirow[t]{2}{*}{ Central location dummy } & & & 0.021 & 0.068 & 0.191 \\
\hline & & & $(0.108)$ & $(0.232)$ & $(0.249)$ \\
\hline Central location & & & & -0.077 & -0.111 \\
\hline Share of trade in GDP & & & & $(0.381)$ & $(0.437)$ \\
\hline Number of observations & 115 & 115 & 115 & 115 & 115 \\
\hline Adjusted $\mathrm{R}^{2}$ & 0.86 & 0.86 & 0.86 & 0.86 & 0.86 \\
\hline
\end{tabular}

Notes: OLS estimation. Dependent variable is the log of population in the main city. The regressions are based on data for the given period available in five-year-intervals. White heteroskedastic-consistent standard errors are in parentheses. **,* and \# denote significant at the $1 \%, 5 \%$ and $10 \%$ level, respectively. Constant not reported.

\footnotetext{
${ }^{7}$ The sample of countries is almost evenly split by the dummy variable. According to the relative distance measure, the five most centrally located primate cities are San Jose (Costa Rica), Kigali (Rwanda), Windhoek (Namibia), Baghdad (Iraq), and Riyadh (Saudi Arabia); the five most peripheral located cities are Papeete (French Polynesia), Suva (Fiji), Kuala Lumpur (Malaysia), Kuwait City (Kuwait), and Mogadishu (Somalia).
} 
Table 2. continued

\begin{tabular}{lccccc}
\hline Time period & \multicolumn{5}{c}{$1985-2000$} \\
\hline Capital city dummy & $0.513^{* *}$ & $0.505^{* *}$ & $0.489^{* *}$ & $0.496^{* *}$ & $0.483^{* *}$ \\
& $(0.145)$ & $(0.143)$ & $(0.149)$ & $(0.155)$ & $(0.146)$ \\
Log of nonurbanized population & $0.436^{* *}$ & $0.424^{* *}$ & $0.424^{* *}$ & $0.427^{* *}$ & $0.415^{* *}$ \\
& $(0.068)$ & $(0.069)$ & $(0.069)$ & $(0.070)$ & $(0.068)$ \\
Log of urbanized population & 0.110 & $0.122 \#$ & $0.129^{*}$ & $0.126 \#$ & $0.126 \#$ \\
outside the main city & $(0.067)$ & $(0.070)$ & $(0.064)$ & $(0.065)$ & $(0.068)$ \\
Log of land area & $0.096^{*}$ & $0.100^{*}$ & $0.087 \#$ & $0.086 \#$ & $0.107^{*}$ \\
& $(0.046)$ & $(0.046)$ & $(0.047)$ & $(0.048)$ & $(0.047)$ \\
Log of real GDP per capita & 0.089 & 0.081 & 0.102 & 0.104 & 0.074 \\
& $(0.107)$ & $(0.108)$ & $(0.109)$ & $(0.113)$ & $(0.111)$ \\
Share of the labor force outside of & $2.054^{* *}$ & $2.071^{* *}$ & $1.976^{* *}$ & $1.969^{* *}$ & $2.081^{* *}$ \\
$\quad$ & $(0.445)$ & $(0.454)$ & $(0.455)$ & $(0.460)$ & $(0.465)$ \\
agriculture & $-0.761^{* *}$ & $-0.888^{* *}$ & $-0.730^{* *}$ & $-0.771^{*}$ & $-0.798^{*}$ \\
Share of trade in GDP & $(0.211)$ & $(0.310)$ & $(0.224)$ & $(0.361)$ & $(0.378)$ \\
Port city dummy & $0.224^{*}$ & 0.057 & & & 0.077 \\
Port city & $(0.106)$ & $(0.242)$ & & & $(0.251)$ \\
Share of trade in GDP & 0.252 & & & & 0.257 \\
Central location dummy & $(0.371)$ & & & & $(0.383)$ \\
Central location & & & -0.038 & -0.083 & 0.143 \\
Share of trade in GDP & & & $(0.102)$ & $(0.268)$ & $(0.256)$ \\
\hline Number of observations & & & & 0.065 & -0.140 \\
Adjusted R ${ }^{2}$ & 108 & 108 & 108 & 108 & 108 \\
\hline Notes: OLS esimtion & 0.83 & 0.84 & 0.83 & 0.83 & 0.84 \\
\hline
\end{tabular}

Notes: OLS estimation. Dependent variable is the log of population in the main city. The regressions are based on data for the given period available in five-year-intervals. White heteroskedastic-consistent standard errors are in parentheses. ${ }^{* *}, *$ and \# denote significant at the $1 \%, 5 \%$ and $10 \%$ level, respectively. Constant not reported.

if port is interacted with openness. While both coefficients are positive, they are not statistically significant at conventional levels. More generally, however, these extensions leave the estimated openness coefficient basically unaffected with slightly higher standard errors. For the central location dummy, the results are even less satisfactory. The coefficients are always insignificant and even change sign for different periods.

Taken together, the empirical results suggest that the geographical location of cities has only a limited impact on the relationship between trade openness and urban concentration. Interaction terms between city location and trade status enter the regression insignificantly, while the standard trade openness coefficient retains 
its size and only marginally loses statistical significance.

\section{Absolute size vs. urban primacy}

The empirical strategy applied above differs from previous attempts to identify determinants of urban concentration in using the absolute size of the country's largest city as dependent variable. Conceptually, this is not necessarily a problem since the log of urban population outside the main city enters the regression as explanatory variable. Specifically, the estimation equation:

$$
\begin{aligned}
& \ln (\text { CITY })=\alpha+\beta_{1} \ln (\text { Urbpop }) \\
& \ln \left(\text { CITY/URBPOP }{ }^{\beta 1}\right)=\alpha+\ldots,
\end{aligned}
$$

close to a regression specification that uses urban primacy, the share of the largest city in urban population [i.e., $\ln (C I T Y / U R B P O P)]$, as dependent variable. In the results in Tables 1 and 2, however, the point estimates on the log of urban

Table 3. Urban Primacy Measures as Dependent Variable

\begin{tabular}{lcccc}
\hline \multirow{2}{*}{ Dependent variable } & \multicolumn{2}{c}{$\begin{array}{c}\text { Log of share of main city } \\
\text { in urban pop. outside the main city }\end{array}$} & \multicolumn{2}{c}{$\begin{array}{c}\text { Log of share of main city } \\
\text { in total urban population }\end{array}$} \\
\hline Time period & $1970-85$ & $1985-2000$ & $1970-85$ & $1985-2000$ \\
\hline Capital city dummy & $0.393 \#$ & $0.493^{* *}$ & 0.309 & $0.443^{* *}$ \\
Log of nonurbanized & $(0.202)$ & $(0.167)$ & $(0.186)$ & $(0.150)$ \\
population & $-0.425^{* *}$ & $-0.419^{* *}$ & & \\
Log of total population & $(0.079)$ & $(0.061)$ & & \\
& $-0.559^{* *}$ & $-0.537^{* *}$ & & \\
Log of land area & $(0.080)$ & $(0.057)$ & & 0.083 \\
& 0.067 & 0.084 & 0.067 & $(0.077)$ \\
Log of real GDP per capita & $(0.084)$ & $(0.076)$ & $(0.091)$ & -0.034 \\
Share of the labor force & 0.242 & -0.087 & 0.106 & $(0.147)$ \\
outside of agriculture & $(0.346)$ & $(0.157)$ & $(0.250)$ & 0.928 \\
Share of trade in GDP & -0.276 & 0.590 & 0.829 & $(0.642)$ \\
& $(1.325)$ & $(0.684)$ & $(0.918)$ & $-0.811^{*}$ \\
& -0.410 & -0.427 & $-1.003 \#$ & $(0.328)$ \\
\hline Number of observations & $(0.418)$ & $(0.335)$ & $(0.512)$ & 108 \\
Adjusted R & 115 & 107 & 115 & 0.46 \\
\hline
\end{tabular}

Notes: OLS estimation. A logistic transformation is applied when the share of the main city in total urban population is the dependent variable. The regressions are based on dataf or the given period available in five-year-intervals. White heteroskedastic-consistent standard errors are in parentheses. ${ }^{* *},{ }^{*}$ and \# denote significant at the $1 \%, 5 \%$ and $10 \%$ level, respectively. Constant not reported. 
population outside the main city are not different from zero at conventional levels of statistical significance. Therefore, it might be useful to modify the regression specification, using explicitly urban primacy as regressand.

In a first set of regressions reported in Table 3, I use the (log of the) share of the main city in urban population outside the main city as dependent variable (that is, I set $\beta_{1}=1$ ). This modification indeed changes the results. Not surprisingly, the coefficient on the log of nonurbanized population becomes negative; in more populous countries a smaller share of the population tends to be concentrated in a central city. Further, the level of economic development (as measured by the share of the labor force outside agriculture) now appears to be uncorrelated with a country's urban concentration. Even more noteworthy is, however, that the coefficient on the variable of interest, the share of trade in GDP, is not significantly different from zero. In this specification, trade openness has no measurable effect on urban primacy.

A second set of estimates applies a more conventional regression specification, using the (log of the) share of the main city in total urban population as dependent variable. ${ }^{8}$ For this limited dependent variable, the coefficient on the trade-to-GDP ratio becomes statistically significant again at conventional levels, but, with $t$ statistics between 1.9 and 2.5 , the coefficient is less precisely estimated than before.

In general, the results highlight the sensitivity of the empirical relationship between openness and urban concentration to the regression specification. A potential explanation for the discrepancy in the results is that primate cities in closed economies may be particularly large relative to cities in open economies, but are probably not that dominant relative to the rest of the national urban system. This hypothesis I will explore next.

\section{Moving down the city size distribution}

For this exercise, I use again (the log of) absolute city size as dependent variable, but now gradually extend the number of cities below the country's largest city in the sample. Interaction variables then capture the extent to which the main city is different from the rest of the city size distribution. ${ }^{9}$ The main source of data is, as before, the UN's World Urbanization Prospects which compiles information on all cities with more than 750,000 inhabitants, filled in with data from Vernon

\footnotetext{
${ }^{8}$ See, for instance, Henderson (2002a).

${ }^{9} \mathrm{Nitsch}$ (2001) proposes a similar approach for historical European data.
} 
Henderson's world cities database. ${ }^{10}$

The results are tabulated in Table 4. At least three observations are noteworthy. First, extending the sample of cities below the main city appears to reduce the significance of the openness variable. For the period 1970-85, openness even enters insignificantly when more than the countries' largest city are included. Second, although the linkage between trade openness and city size appears to be weaker for cities below the first rank, there is no measurable difference in the link for primate cities. In all perturbations, the interaction term on trade openness and the main city

Table 4. Are Main Cities Different?

\begin{tabular}{|c|c|c|c|c|c|c|}
\hline Time period & $1970-85$ & $1970-85$ & $1970-85$ & $1970-85$ & $1970-85$ & $1970-85$ \\
\hline \multirow{2}{*}{ City sample } & Main & Top 2 & Top 3 & Top 4 & Top 5 & Top 5 \\
\hline & City & Cities & Cities & Cities & Cities & Cities \\
\hline \multirow[t]{2}{*}{ Capital city dummy } & $0.414 * *$ & $0.633 * *$ & $0.540 * *$ & $0.415 * *$ & $0.376^{* *}$ & $0.412 * *$ \\
\hline & $(0.119)$ & $(0.116)$ & $(0.113)$ & $(0.142)$ & $(0.136)$ & $(0.130)$ \\
\hline \multirow[t]{2}{*}{ Capital city $\times$ Largest city } & & -0.187 & -0.060 & 0.097 & 0.160 & 0.096 \\
\hline & & $(0.180)$ & $(0.184)$ & $(0.218)$ & $(0.224)$ & $(0.207)$ \\
\hline \multirow[t]{2}{*}{ Log of nonurbanized population } & $0.559 * *$ & $0.577 * *$ & $0.542 * *$ & $0.539 * *$ & $0.532 * *$ & $0.552 * *$ \\
\hline & $(0.060)$ & $(0.082)$ & $(0.080)$ & $(0.077)$ & $(0.086)$ & $(0.064)$ \\
\hline \multirow{2}{*}{$\begin{array}{l}\text { Log of urbanized population } \\
\text { outside the main city }\end{array}$} & 0.052 & 0.069 & $0.137^{*}$ & $0.143 *$ & $0.150 *$ & $0.107 *$ \\
\hline & $(0.049)$ & $(0.065)$ & $(0.064)$ & $(0.056)$ & $(0.063)$ & $(0.047)$ \\
\hline \multirow[t]{2}{*}{ Log of land area } & 0.074 & $0.130^{*}$ & $0.144 * *$ & $0.166^{* *}$ & $0.186^{* *}$ & $0.161 * *$ \\
\hline & $(0.047)$ & $(0.050)$ & $(0.049)$ & $(0.053)$ & $(0.055)$ & $(0.043)$ \\
\hline \multirow[t]{2}{*}{ Log of real GDP per capita } & 0.272 & -0.010 & 0.116 & 0.132 & 0.148 & 0.094 \\
\hline & $(0.175)$ & $(0.147)$ & $(0.132)$ & $(0.145)$ & $(0.152)$ & $(0.125)$ \\
\hline \multirow{2}{*}{$\begin{array}{l}\text { Share of the labor force } \\
\text { outside of agriculture }\end{array}$} & $2.117 * *$ & $3.069 * *$ & $2.532 * *$ & $2.503 * *$ & $2.414 * *$ & $2.649 * *$ \\
\hline & $(0.657)$ & $(0.568)$ & $(0.504)$ & $(0.543)$ & $(0.565)$ & $(0.469)$ \\
\hline \multirow[t]{2}{*}{ Share of trade in GDP } & $-0.746^{*}$ & -0.278 & -0.078 & 0.009 & 0.178 & 0.005 \\
\hline & $(0.310)$ & $(0.417)$ & $(0.377)$ & $(0.389)$ & $(0.388)$ & $(0.316)$ \\
\hline Largest city $\times$ & & -0.025 & -0.066 & -0.053 & -0.168 & -0.378 \\
\hline Share of trade in GDP & & $(0.277)$ & $(0.268)$ & $(0.288)$ & $(0.282)$ & $(0.301)$ \\
\hline Number of observations & 103 & 158 & 219 & 272 & 320 & 394 \\
\hline (countries) & $(103)$ & (79) & (73) & (68) & (64) & (103) \\
\hline Adjusted $\mathrm{R}^{2}$ & 0.85 & 0.85 & 0.86 & 0.86 & 0.88 & 0.86 \\
\hline
\end{tabular}

Notes: OLS estimation. Dependent variable is the log of city population. The regressions are based on data for the given period available in five-year-intervals. White heteroskedastic-consistent standard errors are in parentheses. **, * and \# denote significant at the $1 \%, 5 \%$ and $10 \%$ level, respectively. Constant and controls for city rank in the national size distribution not reported.

\footnotetext{
${ }^{10}$ The data has been gratefully made available by Vernon Henderson at http://econ.pstc.brown.edu/ faculty/henderson/worldcities.html.
} 
Table 4. continued

\begin{tabular}{|c|c|c|c|c|c|c|}
\hline Time period & & & 1985 & 2000 & & \\
\hline & Main & Top 2 & Top 3 & Top 4 & Top 5 & Top 5 \\
\hline cily sampie & City & Cities & Cities & Cities & Cities & Cities \\
\hline Capital city dummy & $0.350 * *$ & $0.669 * *$ & $0.571 * *$ & $0.500 * *$ & $0.473 * *$ & $0.499 * *$ \\
\hline & $(0.128)$ & $(0.197)$ & $(0.167)$ & $(0.159)$ & $(0.156)$ & $(0.146)$ \\
\hline Capital city $\times$ Largest city & & -0.264 & -0.173 & -0.103 & 0.046 & -0.061 \\
\hline & & $(0.256)$ & $(0.237)$ & $(0.242)$ & $(0.243)$ & $(0.221)$ \\
\hline Log of nonurbanized & $0.445 * *$ & $0.497 * *$ & $0.416^{* *}$ & $0.381 * *$ & $0.345^{* *}$ & $0.415^{* *}$ \\
\hline population & $(0.065)$ & $(0.089)$ & $(0.084)$ & $(0.085)$ & $(0.090)$ & $(0.072)$ \\
\hline Log of urbanized population & $0.123 \#$ & 0.084 & $0.177^{*}$ & $0.208 * *$ & $0.220 * *$ & $0.169 * *$ \\
\hline outside the main city & $(0.062)$ & $(0.086)$ & $(0.076)$ & $(0.077)$ & $(0.077)$ & $(0.063)$ \\
\hline Log of land area & 0.069 & $0.128 *$ & $0.133 * *$ & $0.139 * *$ & $0.158 * *$ & $0.142 * *$ \\
\hline & $(0.048)$ & $(0.050)$ & $(0.049)$ & $(0.051)$ & $(0.050)$ & $(0.039)$ \\
\hline Log of real GDP per capita & 0.086 & 0.011 & 0.038 & 0.003 & 0.056 & 0.037 \\
\hline & $(0.111)$ & $(0.120)$ & $(0.129)$ & $(0.123)$ & $(0.133)$ & $(0.110)$ \\
\hline Share of the labor force & $2.011 * *$ & $2.460 * *$ & $2.231 * *$ & $2.305 * *$ & $2.075 * *$ & $2.285^{* * *}$ \\
\hline outside of agriculture & $(0.471)$ & $(0.513)$ & $(0.541)$ & $(0.514)$ & $(0.572)$ & $(0.451)$ \\
\hline Share of trade in GDP & $-0.612 * *$ & $-0.484 \#$ & $-0.436 \#$ & $-0.519 *$ & $-0.569 *$ & $-0.419 *$ \\
\hline & $(0.225)$ & $(0.255)$ & $(0.222)$ & $(0.251)$ & $(0.252)$ & $(0.194)$ \\
\hline Largest city $\times$ & & 0.180 & 0.158 & 0.098 & -0.070 & -0.061 \\
\hline Share of trade in GDP & & $(0.207)$ & $(0.218)$ & $(0.288)$ & $(0.295)$ & $(0.205)$ \\
\hline Number of observations & 111 & 174 & 237 & 300 & 340 & 424 \\
\hline (countries) & (111) & $(87)$ & (79) & (75) & (68) & (111) \\
\hline Adjusted $\mathrm{R}^{2}$ & 0.81 & 0.81 & 0.82 & 0.84 & 0.85 & 0.83 \\
\hline
\end{tabular}

Notes: OLS estimation. Dependent variable is the log of city population. The regressions are based on data for the given period available in five-year-intervals. White heteroskedastic-consistent standard errors are in parentheses. ${ }^{* *}, *$ and $\#$ denote significant at the $1 \%, 5 \%$ and $10 \%$ level, respectively. Constant and controls for city rank in the national size distribution not reported.

is statistically indistinguishable from zero. This result confirms the findings in the previous section: primate cities in closed economies do not have a particularly dominant position in the national urban system. Finally, the capital city effect which suggests that cities with political functions tend to be disproportionately large is not dependent on a country's central city status.

\section{E. Liberalization effects}

Having experimented with several variations of the dependent variable, I now modify the external openness measure. Instead of simply defining openness as the share of trade in GDP, I now focus more explicitly on a country's trade policies. This approach has several advantages. For one thing, trade policy (unlike the trade- 
to-GDP ratio) appears to be completely unrelated to other country characteristics. More importantly, however, this approach deals directly with the policy question of interest, namely: does trade liberalization reduce urban concentration?

To accurately measure a country's overall trade policy stance is a difficult task. Types of trade restrictions vary considerably, ranging from tariff and nontariff barriers to exchange rate distortions and state monopolies, so that different indicators often give different results. ${ }^{11}$ Fortunately, a summary measure is readily available: a dummy variable that classifies countries as open or closed to international trade, constructed by Jeffrey Sachs and Andrew Warner (1995). According to this measure, a country is classified as closed if it displays at least one of the following five characteristics: an average tariff rate of 40 percent and more; nontariff barriers covering 40 percent or more of trade; a black market exchange rate that is depreciated by 20 percent or more relative to the official exchange rate; a state monopoly on major exports; and a socialist economic system. While this methodology is not without criticisms (see Dani Rodrik and Francisco Rodriguez [2000]), Romain Wacziarg and Karen Welch (2003) argue that the dates of trade liberalization derived from both quantitative data and a detailed review of country-specific case studies of reform are a reliable indicator; I use Wacziarg and Welch's corrected and updated data.

In the actual implementation, I run a regression of the form:

$$
\ln \left(C I T Y_{i t} / U R B P O P_{i t}\right)=\alpha+\Sigma_{j} \beta_{j} Z_{i j t}+\delta L I B E R A L_{i t}+\phi_{i}+\eta_{t}+\varepsilon_{i t}
$$

where $Z$ is the same set of conditioning variables as before, LIBERAL is a binary variable which is equal to one if $t$ is greater than the year of trade liberalization (and 0 otherwise), and $\delta$ is the parameter of interest to me. With the inclusion of country fixed-effects $\phi$, estimates of $\delta$ indicate the within-country variation in urban primacy resulting from a discrete change in trade policy openness. A comprehensive set of year dummies, $\eta$, controls for any unobserved time-specific effect.

The results are presented in Table 5. I begin with regression results for LIBERAL set to one when a period of uninterrupted openness began and no reversal of the trade policy reforms occurred, reported in panel (a) of Table 5. As shown, I experiment with several sample periods; the first column tabulates estimates for the full sample, followed by results for two fifteen-year-subperiods. While $\delta$ is indeed negative for the full sample period, the coefficient is statistically indifferent from

\footnotetext{
${ }^{11}$ Reviewing the literature, Andrew Rose (2004) has recently compiled 64 different trade policy indicators.
} 
Table 5. The Effects of Trade Liberalization on Urban Primacy

a) Liberalization date derived from year when uninterrupted openness began

\begin{tabular}{cccc}
\hline Time period & $1970-2000$ & $1970-1985$ & $1985-2000$ \\
\hline Liberal trade regime & -0.009 & 0.016 & 0.008 \\
& $(0.009)$ & $(0.027)$ & $(0.007)$ \\
\hline Number of observations & 635 & 301 & 334 \\
Adjusted $\mathrm{R}^{2}$ & 0.91 & 0.96 & 0.97 \\
\hline
\end{tabular}

b) Additionally allowing for periods of temporary liberalization

\begin{tabular}{cccc}
\hline Time period & $1970-2000$ & $1970-1985$ & $1985-2000$ \\
\hline Liberal trade regime & -0.006 & 0.019 & 0.009 \\
& $(0.008)$ & $(0.019)$ & $(0.007)$ \\
\hline Number of observations & 635 & 301 & 334 \\
Adjusted $\mathrm{R}^{2}$ & 0.91 & 0.96 & 0.97 \\
\hline
\end{tabular}

Notes: OLS estimation with (unreported) year and country fixed effects. Dependent variable is urban primacy defined as the share of the main city in total urban population. The regressions also include the following variables with unreported coefficients: capital city dummy, port dummy, log of nonurbanized population, log of urbanized population outside the main city, log of real GDP per capita, and the share of the labor force outside of agriculture. The regressions are based on data for the given period available in five-year-intervals. Huber-White robust standard errors are in parentheses. ${ }^{* *},{ }^{*}$ and \# denote significant at the $1 \%, 5 \%$ and $10 \%$ level, respectively. The sample comprises 102 countries.

zero. For shorter periods, the coefficient remains insignificant and even takes a positive sign. In Table 5b, LIBERAL is defined to also allow for periods of temporary trade liberalization. The results are largely unchanged. Most notably, none of the estimates of $\delta$ is different from zero at conventional levels of statistical significance. In sum, there is no evidence that countries that have liberalized their trade regime experienced a change (or, for that matter, a decline) in urban primacy.

The large variation in the evolution of urban primacy, unrelated to trade regime, is also illustrated in Figures 1 and 2 which plot some (carefully chosen) case studies. Figure 1 portrays urban concentration patterns for consistently closed economies. As shown, some of these countries experienced an increase in urban primacy (e.g., Angola and Haiti), while for others urban concentration has clearly fallen over time (Republic of Congo) or has followed an inverse bell shaped pattern (Iran, Zimbabwe). The graphs in Figure 2 illustrate a similar variation in the primacy pattern for countries that are relatively open to international trade: urban concentration has rarely declined after trade liberalization.

\section{F. Taking endogeneity seriously}


Figure 1. Urban Primacy and Trade Liberalization - Closed Countries

Algeria (Algiers)

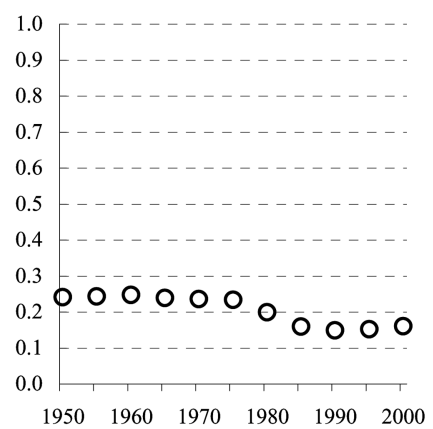

$\begin{array}{llllll}1950 & 1960 & 1970 & 1980 & 1990 & 2000\end{array}$

Haiti (Port-au-Prince)

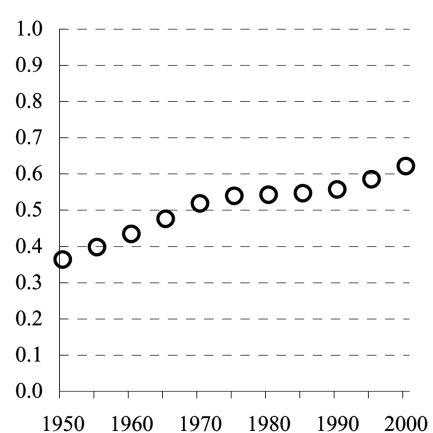

Angola (Luanda)

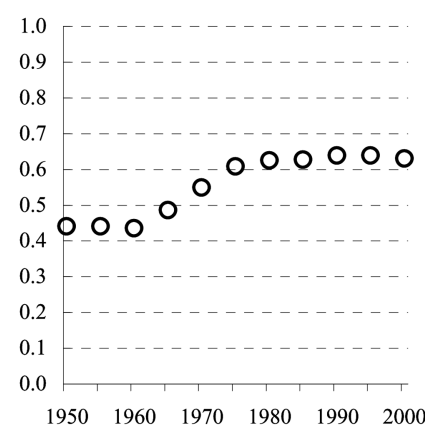

Iran (Teheran)

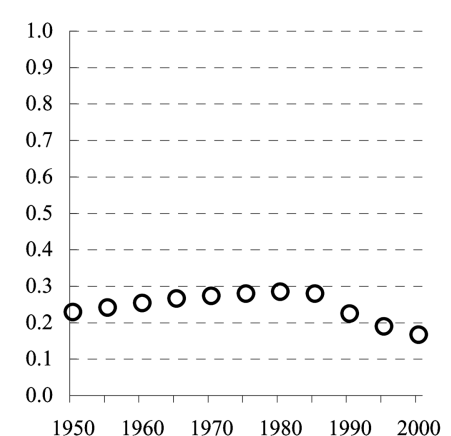

Congo, Dem. Rep. (Kinshasa)

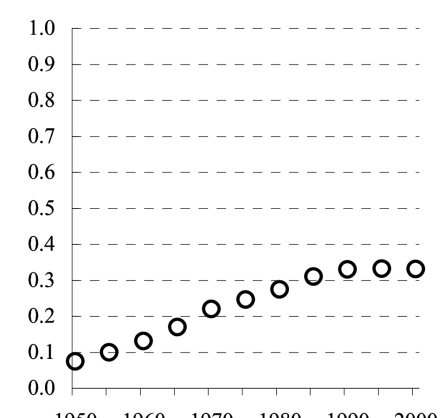

$\begin{array}{llllll}1950 & 1960 & 1970 & 1980 & 1990 & 2000\end{array}$

Myanmar (Yangon)

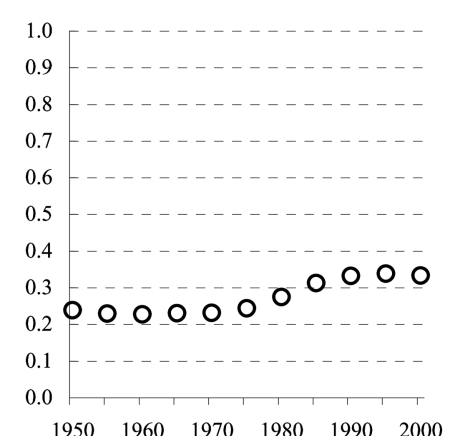

Congo, Rep. (Brazzaville)

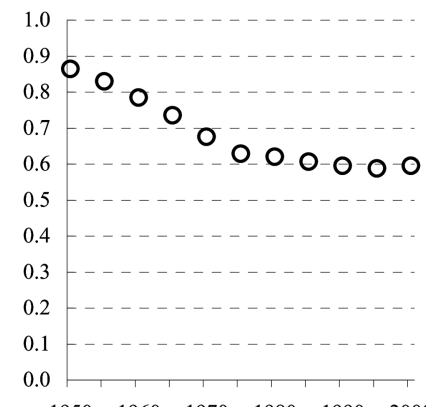

$\begin{array}{llllll}1950 & 1960 & 1970 & 1980 & 1990 & 2000\end{array}$

Zimbabwe (Harare)

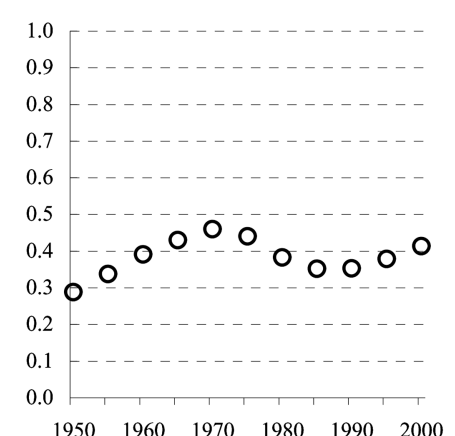


Figure 2. Urban Primacy and Trade Liberalization - Open Countries

\section{Belgium (Brussels)}

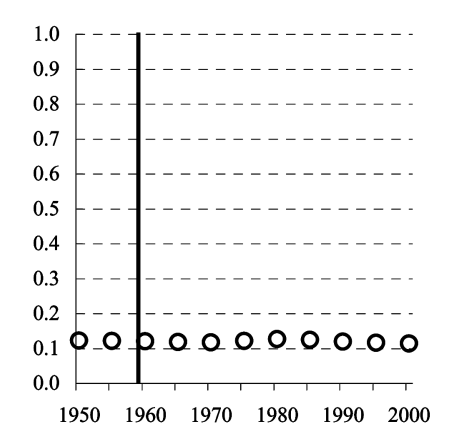

Jordan (Amman)

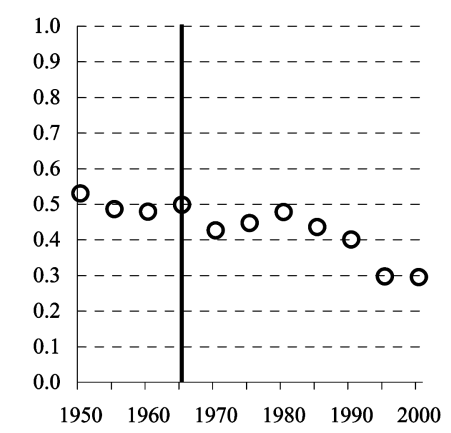

\section{Chile (Santiago)}

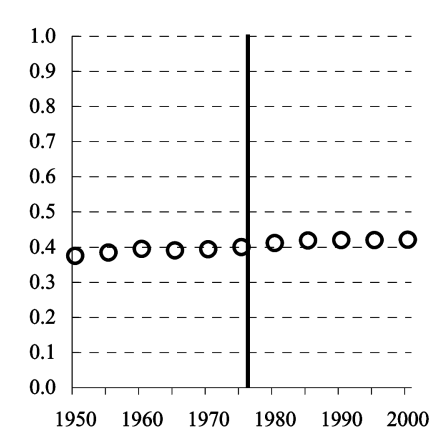

Korea, Rep. (Seoul)

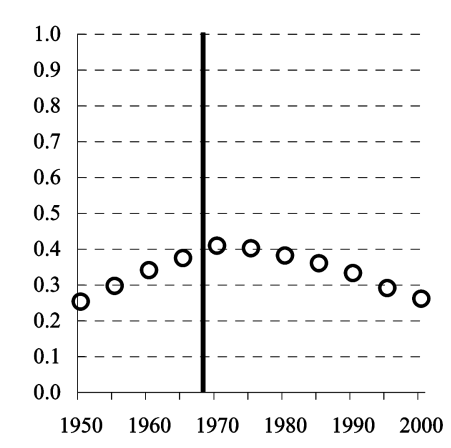

Ghana (Accra)

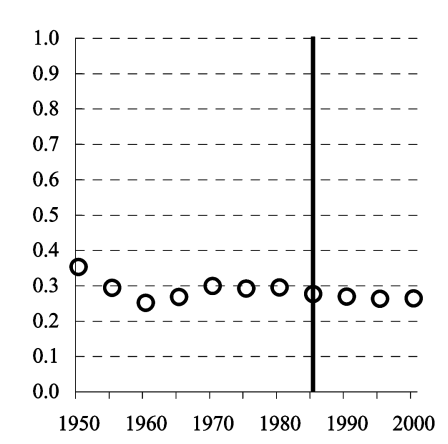

Mexico (Mexico City)

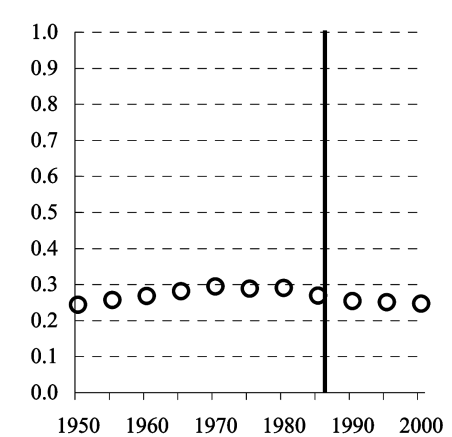

Guinea (Conakry)

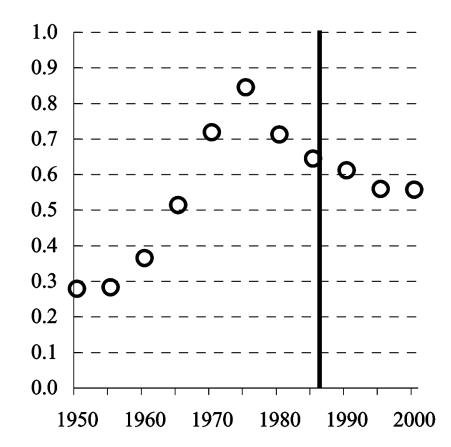

New Zealand (Auckland)

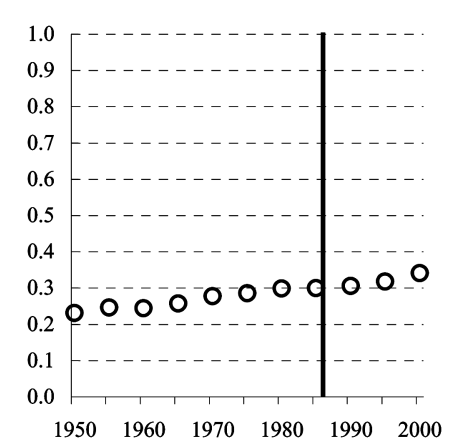


A potential problem of the cross-country regression of urban concentration on trade is endogeneity: a country's trade share may be affected by the degree of urban concentration, with large central cities possibly implying less external trade. Also, replacing trade by measures of countries' trade policies may not effectively solve the problem: changes in a country's economic policies may affect urban concentration and trade openness simultaneously and thereby lead to spurious correlation.

A possible solution is the instrumental variable (IV) approach proposed by Jeffrey Frankel and David Romer (1999). In an attempt to identify the effect of trade on income, Frankel and Romer instrument for the actual trade share by constructing a measure of the geographic component of countries' trade. In particular, they estimate a modified gravity equation (where bilateral trade flows are regressed on countries' geographic characteristics) and then aggregate the fitted trade values. This geography-based trade share appears to be a valid instrument. The measure depends only on geographic characteristics. Moreover, the correlation between the actual and the constructed trade share is a reassuringly high 0.62 .

Table 6 then reports IV estimates that use Frankel and Romer's (1999)

Table 6. Taking Endogeneity Seriously

\begin{tabular}{lcccccc}
\hline Dependent variable & \multicolumn{2}{c}{$\begin{array}{c}\text { Log of population } \\
\text { in the main city }\end{array}$} & $\begin{array}{c}\text { Log of share of main city in } \\
\text { urban pop. outside main city }\end{array}$ & $\begin{array}{c}\text { Log of share of main city } \\
\text { in total urban population }\end{array}$ \\
\hline Time period & $1970-85$ & $1985-2000$ & $1970-85$ & $1985-2000$ & $1970-85$ & $1985-2000$ \\
\hline Capital city dummy & $0.501^{* *}$ & $0.483^{* *}$ & $0.389 \#$ & $0.485^{* *}$ & 0.291 & $0.428^{*}$ \\
& $(0.152)$ & $(0.171)$ & $(0.208)$ & $(0.182)$ & $(0.202)$ & $(0.171)$ \\
Log of nonurbanized & $0.658^{* *}$ & $0.484^{* *}$ & $-0.368^{* *}$ & $-0.378^{* *}$ & & \\
population & $(0.060)$ & $(0.075)$ & $(0.077)$ & $(0.066)$ & & \\
Log of total population & 0.037 & $0.127^{*}$ & & & $-0.454^{* *}$ & $-0.469^{* *}$ \\
& $(0.044)$ & $(0.063)$ & & & $(0.069)$ & $(0.066)$ \\
Log of land area & $0.113^{*}$ & $0.129^{*}$ & 0.102 & 0.123 & 0.082 & 0.108 \\
& $(0.051)$ & $(0.060)$ & $(0.096)$ & $(0.089)$ & $(0.105)$ & $(0.095)$ \\
Log of real GDP per capita & 0.285 & 0.195 & 0.234 & -0.025 & 0.083 & 0.043 \\
& $(0.184)$ & $(0.121)$ & $(0.349)$ & $(0.164)$ & $(0.273)$ & $(0.163)$ \\
Share of the labor force & $2.118^{* *}$ & $1.502^{* *}$ & -0.293 & 0.367 & 0.680 & 0.482 \\
$\quad$ outside of agriculture & $(0.669)$ & $(0.489)$ & $(1.331)$ & $(0.707)$ & $(1.022)$ & $(0.704)$ \\
Constructed share of trade & 0.0015 & 0.0004 & 0.0048 & 0.0012 & -0.0032 & -0.0034 \\
$\quad$ in GDP & $(0.0061)$ & $(0.0062)$ & $(0.0109)$ & $(0.0096)$ & $(0.0102)$ & $(0.0081)$ \\
\hline Number of observations & 115 & 102 & 115 & 101 & 115 & 102 \\
Adjusted R & 0.84 & 0.81 & 0.31 & 0.36 & 0.35 & 0.41 \\
\hline
\end{tabular}

Notes: IV estimation. A logistic transformation is applied when the share of the main city in total urban population is the dependent variable. The regressions are based on data for the given period available in fiveyear-intervals. White heteroskedastic-consistent standard errors are in parentheses. ${ }^{* *},{ }^{*}$ and $\#$ denote significant at the $1 \%, 5 \%$ and $10 \%$ level, respectively. Constant not reported. 
constructed trade share as instrument for trade openness. Treating the trade-to-GDP ratio as endogenous changes the results on the variable of interest considerably. Not only that the estimated coefficient on openness comes down sizably, compared with previous OLS estimates; for all three regression specifications, the effect of openness on primacy is effectively zero. These results provide strong evidence that OLS estimates considerably overstate the effect of trade on urban concentration; in a properly specified regression, there seems to be no causal link between openness and concentration.

\section{Conclusion}

Urban primacy, the extent to which a country's largest city dominates the national urban system, varies considerably across countries. Panama City comprises more than 70 percent of Panama's total urban population, while in neighboring Costa Rica only 42 percent of the national urban population are concentrated in San Jose, and the ratio even drops to 28 percent for Honduras's largest city, Tegucigalpa.

A potential explanation for these differences is that differences in external openness might matter: countries open to international trade tend to have less dominant central cities than close economies, other things equal. In this paper, I examine the empirical evidence for this hypothesis which has recently gained considerable prominence. Providing a large variety of empirical tests, I find at best only weak support for the claim that trade liberalization reduces urban concentration. Moreover, the results suggest that the openness-concentration link is strongly affected by problems of reverse causality and endogeneity.

\section{Acknowledgements}

This paper draws on ideas initially developed in chapter 4 of my dissertation "City Growth in Europe”. I thank my thesis supervisors Dalia Marin and Michael Burda for their encouragement, advice and support. I am also grateful to Luisito Bertinelli, Masahisa Fujita, Henry Overman, Diego Puga, Steve Redding, and participants at the CEPR conference on "The Economics of the Cities", the 2003 meeting of the European Trade Study Group, and the ZEW Summer Workshop on "Innovation, Location and European Integration" for helpful comments and suggestions. Parts of this paper were written while I was an economist at Bankgesellschaft Berlin.

Received 18 April 2005, Accepted 12 December 2005 


\section{Appendix: Primate City Location}

\section{Central location}

Albania

Argentina

Armenia

Bangladesh

Belarus

Belgium

Bolivia

Botswana

Bulgaria

Burkina Faso

Burundi

Cambodia

Cameroon

Tirana

Buenos Aires

Yerevan

Dhaka

Minsk

Brussels

La Paz

Gaborone

/Francistown

Central African Rep.Bangui

Chad

Ndjamena

Chile

Santiago

Colombia

Bogota

Costa Rica

San Jose

Croatia

Zagreb

Czech Republic

Prague

Djibouti

Djibouti

Dominican Rep.

Egypt, Arab Rep.

El Salvador

Estonia

Ethiopia

France

Gambia, The

Georgia

Germany

Guatemala

Guinea-Bissau

Santo Domingo

Cairo

San Salvador

Tallinn

Addis Ababa

Paris

Bathurst

Tbilisi

Essen (Rhein-Ruhr)

Guatemala City

Bissau

\section{Periphery location}

Afghanistan

Kabul

Algeria

Algiers

Angola

Luanda

Australia

Sydney

Austria

Vienna

Azerbaijan

Baku

Bahrain

Al-Manamah

Benin

Porto-Novo

Brazil

Sao Paulo

Canada

Montreal/Toronto

China

Shanghai

Congo, Dem. Rep. Kinshasa

Congo, Rep.

Brazzaville

Cote d'Ivoire

Abidjan

Cuba

Havana

Denmark

Copenhagen

Ecuador

Guayaquil

Fiji

Suva

Finland

Helsinki

French Polynesia

Papeete (Tahiti)

Gabon

Libreville

Ghana

Accra

Greece

Athens

Guinea

Conakry

Iceland

Reykjavik

India

Calcutta/Mumbai

Indonesia

Jakarta

Italy

Milan

Jamaica

Kingston

Almaty

Kuwait City

Vientiane 


\begin{tabular}{|c|c|c|c|}
\hline Guyana & Georgetown & Lesotho & Maseru \\
\hline Haiti & Port-au-Prince & Libya & Tripoli \\
\hline Honduras & Tegucigalpa & Malaysia & Kuala Lumpur \\
\hline Hungary & Budapest & Mali & Bamako \\
\hline Iran, Islamic Rep. & Teheran & Mozambique & Maputo \\
\hline Iraq & Baghdad & Myanmar & Yangon \\
\hline Ireland & Dublin & New Zealand & Auckland \\
\hline Israel & Tel Aviv-Jaffa & Niger & Niamey \\
\hline Japan & Tokyo & Nigeria & Lagos \\
\hline Jordan & Amman & Pakistan & Karachi \\
\hline Kenya & Nairobi & Papua New Guinea & Port Moresby \\
\hline Korea, Rep. & Seoul & Reunion & Saint-Denis \\
\hline Latvia & Riga & Russian Federation & Moscow \\
\hline Lebanon & Beirut & Senegal & Dakar \\
\hline Liberia & Monrovia & Sierra Leone & Freetown \\
\hline Macedonia, FYR & Skopje & Somalia & Mogadishu \\
\hline Madagascar & Antananarivo & South Africa & $\begin{array}{l}\text { Johannesburg } \\
\text { /Cape Town }\end{array}$ \\
\hline Malawi & Lilongwe & Spain & Madrid \\
\hline Martinique & Fort-de-France & Suriname & Paramaribo \\
\hline Mexico & Mexico City & Sweden & Stockholm \\
\hline Mongolia & Ulan Bator & Syrian Arab Rep. & Damascus \\
\hline Morocco & Casablanca & Tanzania & Dar Es Salam \\
\hline Namibia & Windhoek & Togo & Lome \\
\hline Nepal & Kathmandu & Tunisia & Tunis \\
\hline Netherlands & $\begin{array}{l}\text { Rotterdam } \\
\text { /Amsterdam }\end{array}$ & Turkey & Istanbul \\
\hline Nicaragua & Managua & $\begin{array}{l}\text { United Arab } \\
\text { Emirates }\end{array}$ & Dubai \\
\hline Norway & Oslo & United Kingdom & London \\
\hline Panama & Panama City & United States & New York \\
\hline Paraguay & Asuncion & Uruguay & Montevideo \\
\hline Peru & Lima & Uzbekistan & Tashkent \\
\hline Philippines & Metro Manila & Vietnam & Ho Chi Minh City \\
\hline Poland & Katowice & Yemen, Rep. & Sana'a \\
\hline Portugal & Lisbon & & \\
\hline
\end{tabular}




$\begin{array}{ll}\text { Central location } & \text { (cont.) } \\ \text { Puerto Rico } & \text { San Juan } \\ \text { Romania } & \text { Bucharest } \\ \text { Rwanda } & \text { Kigali } \\ \text { Saudi Arabia } & \text { Riyadh } \\ \text { Sri Lanka } & \text { Colombo } \\ \text { Sudan } & \text { Khartoum } \\ \text { Switzerland } & \text { Zurich } \\ \text { Thailand } & \text { Bangkok } \\ \text { Uganda } & \text { Kampala } \\ \text { Ukraine } & \text { Kiev } \\ \text { Venezuela } & \text { Caracas } \\ \text { Yugoslavia, FR } & \text { Belgrade } \\ \text { (Serbia/Montenegro) } \\ \text { Zambia } & \text { Lusaka } \\ \text { Zimbabwe } & \text { Harare }\end{array}$

\section{Periphery location (cont.)}

\section{References}

Ades, A., E. Glaeser (1995) Trade and Circuses: Explaining Urban Giants, Quarterly Journal of Economics. 110, 195-227.

Alperovitch, G. (1993) An Explanatory Model of City-Size Distribution: Evidence from Cross-Country Data, Urban Studies. 30, 1591-1601.

Carroll, G. (1982) National City-Size Distributions: What Do We Know After 67 Years of Research?" Progress in Human Geography. 6 (March): 1-43.

Frankel, J., D. Romer (1999) Does Trade Cause Growth?" American Economic Review. 89, 379-399.

Gustavsson, R. (1999) Explaining the Phenomenon of Third World Urban Giants, Journal of Economic Integration. 14 (December): 625-650.

Hanson, G (1998) Regional Adjustment to Trade Liberalization, Regional Science and Urban Economics. 28 (July): 419-444.

Henderson, V. (1996) Ways to Think About Urban Concentration: Neoclassical Urban Systems versus the New Economic Geography, International Regional Science Review. 19, 31-36.

Henderson, V. (2000) The Effects of Urban Concentration on Economic Growth, NBER Working Paper \#7503.

Henderson, V. (2002a) Urban Primacy, External Costs, and Quality of Life, Resource and Energy Economics. 24, 95-106.

Henderson, V. 2002b. Urbanization in Developing Countries, World Bank Research 
Observer. 17 (Spring): 89-112.

Henderson, V. (2003) The Urbanization Process and Economic Growth: The So-What Question, Journal of Economic Growth. 8, 47-71.

Junius, K. (1999) Primacy and Economic Development: Bell Shaped or Parallel Growth of Cities?" Journal of Economic Development. 24, 1-22.

Krugman, P. (1996) Urban Concentration: The Role of Increasing Returns and Transport Costs, International Regional Science Review. 19: 5-30.

Krugman, P., G. Hanson (1993) Mexico-U.S. Free Trade and the Location of Production, in The Mexico-U.S. Free Trade Agreement (Ed). Garber, P., MIT Press, Cambridge, MA

Krugman, P., R. Elizondo (1996.) Trade Policy and Third World Metropolis, Journal of Development Economics, 49, 137-150.

Moomaw, R., M. Alwosabi. (2003) Urban Primacy, Gigantism, and International Trade: Evidence from Asia and the Americas, ZEI Working Paper B20-2003

Moomaw, R., M. Alwosabi (2004) An Empirical Analysis of Competing Explanations of Urban Primacy: Evidence from Asia and the Americas, Annals of Regional Science, $38,149-171$

Moomaw, R., A. Shatter (1996) Urbanization and Economic Development: A Bias Toward Large Cities? Journal of Urban Economics. 40 (July): 13-37.

Mutlu, S. (1989) Urban Concentration and Primacy Revisited: An Analysis and Some Policy Conclusions, Economic Development and Cultural Change. 37, 611-639.

Nitsch, V. (2001) City Growth in Europe. Duncker \& Humblot, Berlin

Rappaport, J., J. Sachs (2003) The United States as a Coastal Nation, Journal of Economic Growth, 8, 5-46.

Rodrik, D., F. Rodriguez (2000) Trade Policy and Economic Growth: A Skeptic's Guide to the Cross-National Evidence, in NBER Macroeconomics Annual 2000 (Ed.). Bernanke, B., Rogoff, K., MIT Press, Cambridge, MA

Rose, A. (2004) Do WTO Members Have More Liberal Trade Policy? Journal of International Economics. 63, 209-235.

Sachs, J., A. Warner (1995) Economic Reform and the Process of Global Integration, Brookings Papers on Economic Activity, 1-118.

Soo, K. (2003) Zipf's Law for Cities: A Cross Country Investigation, London School of Economics.

Venables, A. (2000) Cities and Trade: External Trade and Internal Geography in Developing Economies," in Local Dynamics in an Era of Globalisation: 21 st Century Catalysts for Development (Ed.) Yusuf, S., Wu, W., Evenett, S., World Bank, Washington, D.C.

Wacziarg, R., K. Welch (2003) Trade Liberalization and Growth: New Evidence, NBER Working Paper \#10152.

World Bank. 2003. World Development Report 2003: Sustainable Development in a Dynamic World. World Bank, Washington, D.C. 